\title{
Download
}

UDC 656.7: 910.3 https://doi.org/10.17721/2308-135X.2021.61.44-51

Kolotukha Igor Olexandrovich, Candidate of Geographical Sciences Kirovograd Regional Center of Tourism, Local Lore and Excursions of Student Youth, Kropyvnytskyi, Ukraine, e-mail: kolotuha.igor@gmail.com

Kolotukha Oleksandr Vasyliovych, Doctor of Geographical Sciences, Associate Professor Flight Academy of the National Aviation University, Kropyvnytskyi, Ukraine,

e-mail: okolotuh@ukr.net

\section{AIR TRANSPORT AS OBJECT OF SOCIAL AND GEOGRAPHICAL RESEARCH}

The purpose of the study is to consider the socio-geographical principles of air transport research, to determine the role of air transport geography in the system of geographical science, to define the object and subject of air transport geography, to determine the indicators of socio-geographical analysis of air transport.

Method. Transport development has led to scientists' collaboration in different specialties for studying this phenomenon that enables to determine the interdisciplinary nature of this research, as transport is studied by a number of scientific disciplines, such as economic, environmental, technical sciences, logistics, and, specifically, geography. The multidimensional nature of transport as a social and economic phenomenon has determined a problem-based approach to its scientific and applied research. In this case, in contrast to other disciplines, geography is primarily interested in the transport spatial dimension, namely the spatial features of transport interaction with the territory, nature, population and economy. Air transport geography is an important component of transport geography. 
Results. Air transport geography should be defined as a scientific unit of transport geography, which studies the territorial structure of air transport, transport corridors, patterns and features of location, the level of transportation of countries and groups of countries. Air transport geography is an important component of transport geography, its scientific unit, with a specific object and subject of research, the main directions and indicators for socio-geographical analysis of world and national air transport. The indicators for such analysis are the following: geography of air corridors and network of air transport routes; world airport network; main aviation passenger flows and their dynamics; passenger traffic in comparison with other means of transport and their dynamics in recent years.

Scientific novelty. Improving the theoretical, methodological and methodical apparatus of transport geography in general (improving the classification of means of transport) and its component - air transport geography in particular, expanding their subject and object sphere and conducting applied research on an updated basis.

Practical value. The main practical value of research on air transport geography is considered the development of plans and recommendations for improving the location of production and resettlement in terms of minimizing transport costs, optimizing air traffic flows within existing territorial transport systems, development of air transport systems at all levels.

Key words: transport, transport system, geography of transport, air transport, air transport geography.

References

1. Alaev E. Economic and geographical terminology. M .: Mysl, 1977. 199 p.

2. Bugromenko V. Transport in territorial systems. M .: Nauka, 1987. $112 \mathrm{p}$.

3. Dudnik I. Transport geography: a textbook. K .: NAU, 2016. 288 p. 
4. Kolotukha I. Urban public transport as an object of socio-geographical research. Geography and tourism: a scientific collection. City of Education and Science of Ukraine, Kyiv. Nat. Univ. Taras Shevchenko. K., 2016. Vip. 35. Pp. 179-188.

5. Pashchenko Y. Development and location of the transport and road complex of Ukraine. NAS of Ukraine, Council for Product Study. Forces of Ukraine, ed. S. Doroguntsov. K .: Scientific World, 2003. 468 p.

6. Redin V. Features of the territorial organization of transport activities in the Kharkiv region. Journal of Socio-Economic Geography. 2008. №5. Pp. 112-115.

7. Tarkhov S. Geography of transport. The Great Russian Encyclopedia. M., 2006. T.6. Pp. 593-594.

8. Tarkhov S., Semina I. Geography of transport as a branch geographical science. Current issues of geography and geoecology. Mordovia State University N. Ogareva, 2009. №1 (5). Pp. 93-104.

9. Topchiev O. Socio-geographical research: methodology, methods, techniques. Odessa: Astroprint, 2005. $632 \mathrm{p}$.

10. Ullman E. Geography of transport. American Geography: Current Status and Prospects. M .: publishing house of foreign literature, 1957. $378 \mathrm{~s}$.

11. Khakhlyuk A. Infrastructure industries in the world economy // In the book. World Economy, ed. Filipenko A. K .: Lybid, 2001. P.282.

12. Tsvetov Yu. Transport: a systems approach (questions of theory and practice). M .: Znanie, 
v616

Written by Administrator

Tuesday, 25 January 2022 11:31 - Last Updated Thursday, 14 July 2022 14:47

1980. 64 p.

13. Rodrigue J.-P. The Geography of Transport Systems. Fourth edition. New York: Routledge, 2017. $440 \mathrm{p}$. 